\title{
Мистецтвознавство
}

УДК 785.071.021.42

\author{
Єргієв Іван Дмитрович \\ доктор мистецтвознавства, професор, \\ завідувач кафедри народних інструментів \\ Одеської національної музичної академії \\ імені А. В. Нежданової, \\ Народний артист України \\ ORCID 0000000186232010 \\ yergiyev.akk@gmail.com
}

\section{ФЕНОМЕН АВТОРСЬКО-ВИКОНАВСЬКОЇ ПОСТНЕОКЛАСИЧНОЇ ТВОРЧОСТІ ЯК НАУКОВА ПРОБЛЕМА (діалектично-творча колізія «автор-артист»)}

\begin{abstract}
Мета статті - дослідити одну з найважливіших проблем теорії та естетики музики - авторськовиконавську творчість як процес і результат двох різних видів діяльності, співвіднесеності авторської заданості і авторсько-виконавської ініціативи в якості артистичної інтерпретації власного твору. Методологія дослідження будується на міждисциплінарних підходах, оскільки у вивченні та конституюванні авторської музичної творчості як феномена сучасної культури виникають численні питання, що охоплюють широкі обрії культурно-мистецького поля. Використовуються класичні, дієві для музикознавчого дослідження методи: аналітичний, аудіо-візуальний, компаративний, ін. Наукова новизна полягає в тому, що проблема авторської гри-інтерпретації власного музичного твору, або самоінтерпретації ніколи не була об'єктом спеціального дослідження у філософськопсихологічному і музикознавчому дискурсі. Висновки. В результаті дослідження (дискурс-аналізу існуючої літератури з даної проблеми, опитування авторів музики, аналізу власної авторсько-артистичної творчості, ін.) встановлено, що амбівалентність колізії авторсько-артистичної творчості існує на межі композиторського і виконавського мислення, відповідно - музичної мови автора і музичного мовлення виконавця, і вирішується за рахунок парціальності, часткового «роздвоєння» особистості творця-виконавця, який сам довершує своє (твір) в безлічі оновлених інтерпретацій.
\end{abstract}

Ключові слова: авторсько-артистична прем'єра, артистична концепція, виконавський музичний твір, гратворчість, творча колізія, синергетична творчість.

Ергиев Иван Дмитриевич, доктор искусствоведения, профрессор, заведующий кафедрой народных инструментов Одесской национальной музыкальной академии им. А. В. Неждановой

Феномен авторско-исполнительского постнеоклассического творчества как научная проблема (диалектико-творческая коллизия «автор-артист»)

Цель статьи - исследовать одну из важнейших проблем теории и эстетики музыки - авторскоисполнительское творчество как процесс и результат двух различных видов деятельности, соотнесенность авторской заданности и авторско-исполнительской инициативы в качестве артистической интерпретации собственного сочинения. Методология исследования строится на междисциплинарных подходах, поскольку в изучении и конституировании авторского музыкального творчества как феномена современной культуры возникают многочисленные вопросы, которые охватывают широкие горизонты культурно-художественного поля. Используются классические, действенные для искусствоведческого исследования методы: аналитический, аудио-визуальный, компаративный, др. Научная новизна заключается в том, что проблема авторской игры-интерпретации собственного музыкального произведения, или самоинтерпретации никогда не была объектом специального исследования в философско-психологическом и музыковедческом дискурсе. Выводы. В результате исследования (дискурс-анализа существующей литературы по данной проблеме, опроса авторов музыки, анализа собственного авторско-артистического творчества, др.) установлено, что амбивалентность коллизии авторско-артистического творчества существует на грани композиторского и исполнительского мышления, соответственно - музыкального языка автора и музыкального высказывания исполнителя, и решается за счет парциальности, частичного «раздвоения» личности творца-исполнителя, который сам довершает свое (произведение) во множестве обновлённых интерпретаций.

Ключевые слова: авторско-артистическая премьера, артистическая концепция, исполнительское музыкальное произведение, игра-творчество, творческая коллизия, синергетическое творчество.

Jerghijev Ivan, Doctor of Arts, Professor, Head of the Department of Folk Instruments, Odessa National Music Academy A. V. Nezhdanova

The phenomenon of author-performer's post-neoclassical creativity as a scientific problem (dialectical and creative collision "author-artist")

The purpose of the article is to investigate one of the most important problems of the theory and aesthetics of music - the author-performer's creativity as a process and the result of two different types of activity, correlation between

() Єргієв І. Д., 2020 
the direction set by an author and the author-performer's initiative as an artistic interpretation of his own composition. The methodology of the research is based on interdisciplinary approaches since the study and constitution of the author's musical creativity as a phenomenon of modern culture raises many problematic issues, which cover wide horizons of cultural and artistic fields. The author uses classical methods that are effective for art history research: analytical, audio-visual, comparative, etc. The scientific novelty lies in the fact that the problem of an author's game-interpretation of his own musical work, or self-interpretation has never been the subject of special research in philosophical, psychological and musicological discourse. Conclusions. As a result of the research (a discourse analysis of existing literature on this problem, a survey of music authors, analysis of author's own author-artistic creativity, etc.) it was found that the ambivalence of a collision of author-artistic creativity exists on the verge of composer's and performer's thinking, respectively the musical language of an author and the musical statement of an artist, and is solved by the means of partiality, partial "bifurcation" of the creator-performer's personality, who himself completes his (work) in many renewed interpretations. For the practical solution of the problem under study, it is important that the author understands the endpoint (terminus ad quem) of his creative product, which he needs to reach as an artist - spiritual perception, aesthetic impression of the viewer-listener from the complete meaningful form of the author's musical performance in the artistic version.

Key words: author-artistic premiere, artistic concept, performer's musical work, creative play, creative collision, synergetic creativity.

Актуальність теми дослідження. В світовій музичній культурі всіх часів унікальне місце посідає феномен творчості автора музики - виконавця-артиста. Сам акт народження музики (тим більш поява на світ музичного шедевру) завжди вважався якоюсь таємницею - божим провидінням. Саме метафрізичні погляди на появу музичних артефактів, специфіка авторської гри-інтерпретації власного музичного твору, а також і брак наукових розвідок даної проблеми спонукають до вивчення цього феномену.

Мета статі - дослідити одну з найважливіших проблем теорії та естетики музики - авторськовиконавську творчість як процес і результат двох різних видів діяльності, співвіднесеності авторської заданості і авторсько-виконавської ініціативи в якості артистичної інтерпретації власного твору.

Аналіз досліджень і публікацій. Окремі аспекти зазначеної проблеми висвітлені в роботах композиторів, музикознавців і виконавців. Зокрема це стосується еволюції композиторської техніки (Е. Денісов), закономірностей і засобів художнього впливу музики (В. Медушевський), творчого аспекту музичної інтерпретації (В. Москаленко), розкриття френомена інструментальної гри (К. Єргієва), ін.

Виклад основного матеріалу. Перегортаючи сторінки історії східної і західної музичних культур, зайвий раз переконуєшся, що від самого початку, в онтогенезі творчість музиканта була синкретичною, поєднуючи в собі і створення музики, і її виконання: або в певній часовій дистанції, або одночасно у грі-імпровізації.

Синкретизм творчості поета-музиканта-танцюриста з відокремленням гри на інструменті від пісні і танцю поступово трансформувався в універсалізм автора-гравця - музиканта-ремісника.

Така ситуація трималася досить довго. Ще сто років тому мабуть складно було б уявити людину, яка б називала себе музикантом і при цьому не створювала музику (музичні опуси).

У XX столітті європейське професійне музичне мистецтво вперше за багатовікову історію зазнало «розкол» - розподіл на композиторів-авторів і виконавців-інтерпретаторів «чужих» текстів. Композитори «делегували» сценічну гру виконавцям. В значній мірі це сталося завдяки натиску двох хвиль музичного авангарду (першої третини XX ст. і 50-их років).

Ситуація в академічній інструментальній музиці почала потроху змінюватися в кінці $\mathrm{XX}$ століття вже під впливом альтернативних їй напрямків: джаз, рок, сфера популярної музики (легкої естрадно-розважальної), електронної, в яких склалися свої традиції і закони створення музичних композицій. Останні часто так і не знаходили письмової (нотної) фріксації. Так звані «альбоми», «концерти» рок-гуртів переважно існували в усній імпровізаційній фрормі і згодом фріксувалися на звуко- та відео-носіях (плівках, дисках, кліпах, ін.). Тобто авторські музичні твори спочатку з'являлися в живій концертно-комунікативній формі ${ }^{1}$.

У будь-якому разі ми маємо справу з музичним твором як семіотичним об'єктом, який має «подвійну, матеріально-ідеальну природу: <...> фріксується в звучанні і тому почуттєво сприймається $<$...>» (курсив мій. - I. Є.) [8, 9].

Для автора його музичний твір перебуває в трьох іпостасях: перша - ідеально-суб'єктивна, що існує тільки для творця в його свідомості завдяки слуховій уяві; друга - об'єктивна (матеріальна, семантична), тобто зафріксована як структура в письмових знаках - оригінальному нотному тексті; третя - об'єктивно-суб'єктивна, тобто та, що звучить (семіологічна) завдяки виконавцю, який зазвичай інтерпретує чужий текст.

Як правило, стимулом для створення нового музичного твору композитором є міцна сила емоційного враження від якогось явища, події, людини, предмета, будь-якого іншого подразника, його переживання.

Результат цього враження - емоційно-інтонаційна ідея нового твору (згодом вербалізована). Е. Денисов, характеризуючи початковий етап композиційного процесу, на перший план ставить «виникнення загальної ідеї твору і концепції форми» (курсив мій. - I. Є.) [4, 12]. Поява теми (одне з таємничих явищ) $є$ відправною точкою (terminus a quo) творчого процесу. 
Тема, за версією В. Москаленко, - це «реально або подумки виконуваний рельєфрноконструктивний комплекс, який в процесі музичного мислення слугує психологічно опорним фактором формо-творчості з функцією становлення, засвоєння і розвитку музичної образності твору» (курсив мій. - І. Є.) [9,65].

Автор статті як композитор часто стикався з еврістичною ситуацією, коли фрізично відчуваєш спалах натхнення (часто навіть під час сну), коли вже свідомо (мисленнєво) намагаєшся «схопити за хвіст» основну інтонаційну ідею, яка й є виразом чогось дійсно нового, якого ніколи не було, тобто творчості у чистому вигляді ${ }^{2}$.

Музичне переживання теми (основної мелодії) твору в процесі гри виконавця на музичному інструменті (співу) є одним з виразів «естетичного відношення» до дійсності у вигляді супутній даній грі «<...> активної енергетичної основи» (виділено мною. - І. Є.) [17, 396].

Відповідно, стимулом для вибору та розучування того чи іншого твору у виконавця має бути міцне емоційне (енергетичне) збудження, враження від композиції. Сильний потяг до останньої має викликати велике бажання виконавця до висловлення, говоріння на музичному інструменті.

Автора музики під час роботи над музичним твором та її виконавця під час гри характеризують творчі - змінені стани свідомості (ЗСС). У композитора це пов'язано зокрема з так званою нав'язливістю, коли наспівується («програвається») в уяві той чи інший мотив, мелодійний оборот, пасаж і т. ін.

У виконавця вхід у ЗСС як елемент артистичної психотехніки дозволяє «включити підсвідомість як генератор виконавської творчості в аспектах інтуїції, імпровізації, музикування - вищих показників рівня гри, у єдиному цілому в «наскрізному розвитку», спрямованих на "завоювання" публіки» [5, 249].

Існують дві різні техніки: композиторська і виконавська з певним набором виразових засобів. Ці техніки обумовлені сутністю тієї чи іншої діяльності, ії метою і, відповідно. - специфікою мислення.

Композиторське мислення і виконавське - це різні за своєю специфікою види мислення. Кінцева мета будь-якого автора академічної музики - зафріксувати, увічнити свою композицію (втілення ідеї в певних образах) - в нотному тексті (інваріанті) завдяки композиторській техніці, «квантом» якої $\epsilon$ нотний знак.

Артист, «вмикаючи» виконавське мислення, мріє створити за допомогою гри-інтонування еталонну інтерпретацію. Результативним «квантом» виконавського інтонування є звукоінтонація.

Цікаво простежити, в чому спільність цих технік і в чому принципова відмінність, безумовно в рамках, обмежених обсягом статті.

Саме в реалізації цих двох технік і існує музичний твір. В добу постнеокласицизму - розквіту поза-академічних напрямків музики, домінування нелінійних форм мислення і «відкритих» текстів техніка виконавців тяжіє до універсалізму.

Загальновідомо, що головним фактором як композиторської, так і виконавської творчості $€$ уява (франтазія), яка являється одним з численних психічних процесів, задіяних в творчому акті. I композитор, і виконавець, якщо ми говоримо саме про музичне мистецтво, прагнуть втілити нові ідеї, створити нові художні образи. Недарма О. Потебня підкреслював, що «без образу немає мистецтва» [10, 284].

Прийоми створення музичних образів на основі уяви наступні: аглютинація (створення нових образів шляхом «склеювання» різних частин, якостей, властивостей), аналогія (звуконаслідування, «мімезис»), акцентування (підкреслення рис, що мають суттєве значення для характеристики образу), гіперболізація (перебільшення або применшення цілого або окремих частин), схематизація (злиття, при якому згладжуються відмінності, а риси подібності достатньо чіткі), типізація (виділення суттєвого), ін., які спрацьовують завдяки досконалій техніці композиції і виконавській художній техніці - «гріmворчості» ${ }^{3}$.

Результатом роботи композиторської техніки стає музичний твір, оформлений в тексті, a peзультатом виконавської художньої техніки виявляється «колоритна тембро-сонорна інтонаційна матерія неповторного виконавського музичного твору, збагачена <...> новими символами, асоціаціями та метафоричними смислами» (курсив мій. - I. Є.) [6, 212].

Виконавець прагне, «<..> щоб інтонування призвело до колективно засвоєної інтонації» (курсив мій. - І. Є.) $[9,61]$.

Оскільки музика - це часове процесуальне мистецтво, можна вважати процесуальність однією з найсуттєвіших властивостей композиторської і виконавської діяльності. Однак в цих двох видах творчої діяльності вона різна.

Характеризуючи музичний твір як «фріксований» об'єкт, Н. Герасимова-Персидська відмічає, що «<.. > він поєднує позачасову (в певному сенсі) стійкість і неминучу процесуальність» (курсив мій. - I. Є.) $[3,295]$.

Часовий параметр як «відношення музичного твору і процесу», на думку авторки, «проявляється двояко: в побутуванні твору - як його включення в час світу, так би мовити, в історію, і в самому творі - як музичний час» [там само]. 
Композиторська процесуальність діахронічна. Вона може бути дискретною, тобто розгорнутою в часі (час створення і реальна тривалість твору як правило не співпадають) і різновекторною: як зворотною, так і з «забіганням» вперед.

Відмінність виконавської синхронічної процесуальності полягає в наявності постійного кінематичного руху. Час звучання виконавського твору («живого тексту») приблизно співпадає з авторським задумом.

Жива фрорма авторського музичного твору, яка створюється в певному часопросторі, відрізняється мобільністю за рахунок використання мобільних засобів виконавської художньої виразності: темпо-ритму, агогіки, акцентуації, штрихів, б. ін.

Наступна важлива властивість обох технік - синергія. У створенні автором музики (музичного твору) приймають участь чотири психічні енергії: несвідомого (Ics), підсвідомого (Pcs), cвідомого (Cs) і «надсвідомого». Остання спрацьовує при наявності у індивіда трансцендентальної інтуїції (термін автора. - І. Є.), яка дає можливість підключатися і «зчитувати» інфрормацію з генерального «космічного» серверу.

Тут доцільно говорити про феноменологічну редукцію як сукупність різних редукцій: феноменолого-психологічної, ейдетичної та трансцендентальної, що призводить до авторської еврістичHOCmi.

Артистична (виконавська) синергія являє собою «енергетичну суму рухів душі (психіки), розуму, тіла (і інструмента): переживання як “потік” (рух) художньої свідомості <...>» [5, 450].

В порівняльному дискурс-аналізі композиторської та виконавської творчості доречно згадати і про ефекти «зараження» (емоційність) і «навіювання» (ідейність) у виконавській і композиторській техніці. В сучасній виконавській практиці артистів академічної традиції домінує психологічна концепція гри на інструменті з первинною установкою не тільки на озвучення-інтонування музичного матеріалу твору згідно канонам, нормам, правилам, а й на вплив як звучної матерії музичного твору - ідеальноматеріальної смисло-енергетичної субстанції, так і самого музиканта-гравця (разом - одного цілого) на аудиторію, що приводить останню в стан «трепету».

Ефект подібного «трепету» відзначається багатьма дослідниками, зокрема Г. Вільсоном, який називає його «крайньою фрормою реакції на музику» [2, 225-226], що може супроводжуватися появою «гусячої шкіри» (пілоерекції), або, «як у народі кажуть», - «мурашок».

У артиста з особливою силою «енергії зовнішнього світу перетворюється аналізаторами в нервові фрізіологічні імпульси, які міняють біохімічну природу. Такі імпульси йдуть у мозок, внаслідок чого утворюється суб'єктивний образ (О.) того, що відчувається (сприймається). Перетворення енергї зовнішнього роздратування у факт свідомості фіксується у вигляді сенсорного О. Особливості відображуваного об'єкта «кодуються» у нервових процесах, утворюється своєрідна нервова модель О.» (курсив мій. - І. Є.) $[11,108]$.

В академічному виконавському мистецтві, яке націлене на натхненне творення «живого» художнього образу живим виконавцем в «живому» виконанні, головним стає переживання: сила враження, сила почуттів, емоцій, експресія звучання і зовнішньої динаміки поведінки артиста. В іншому випадку може скластися ситуація, коли ефекти «зараження» і «навіювання» закодовані композитором в нотному тексті, а «емоційне напруження, яке виражається мелодійно-теситурними, гучністними, тембровими, гармонійними засобами, слухач може розпізнати холодно <...» [8, 37].

Ефект композиторського навіювання безпосередньо залежить від «<...> соціальної значущості ідеї (основи змісту музичного твору - I. Є.), що виражається» (курсив і вставка мої. - I. $€$.) $[8,38]$.

3 ефектом виконавського навіювання, тобто транзитивністю концептуальних ідей від виконавця до глядача-слухача все набагато складніше.

Автор статті як артист багато разів задавався питанням: чи можливе інформаційно-інтонаційне кодування виконавських ідей та їх трансляція глядачу-слухачу? Відповідь дає концертна практика 3 опитуванням глядачів-слухачів. Вона верифікує можливу транзитивність ідей-емоцій в артистів 3 підвищеною експресією гри, яка може спровокувати необхідний напрямок думки реципієнта, ії усвідомленість та адекватну вербалізацію (боротьба добра і зла, радість буття, ін.).

Супутнім до проаналізованих ефектів «зараження» і «навіювання» в досліджуваній колізії $є$ так звана полярність емоцій. Наступна відмінність двох технік криється в логіці емоційних переходів (перетікання, лабільності емоційних станів). 3 одного боку маємо емоційні пропорції музичного твору, позначені авторськими ремарками, а з іншого - інтенсивність втілюваних емоцій, яку виконавець має регулювати, використовуючи особистий «енергетичний інструмент» - писхотехніку, виходячи з програми, заданої автором. Слід однак зауважити, що під час написання музичного твору в процесі, розтягнутому в часі, автор не в змозі весь час бути в стані «наелектризованості» справжніми естетичними емоціями і, більш того, втілити абсолютно точно їх протікання.

Виконавець концентрує емоційні переживання в стислому часі в процесі гри, і, володіючі артистичною психотехнікою, повинен кожний раз оновлювати модальність і створювати новий емоційний «трафрік». У артиста-автора, який повністю віддається грі-творчості, виникає сценічний інсайт (своєрідний «політ» франтазії) - спонтанний (незапланований, незафіксований в знаках) прорив у новий інто- 
наційний простір, в якому він навіть несподівано для себе відкриває нові грані особистісного музичного образу власного музичного твору.

У композитора творчість найяскравіше проявляється в еврістичності. Ю. Холопов відмічає, що «істинною основою музичної творчості є рельєфрний доброякісний тематизм - носій музичної образності» (курсив мій. - І. Є.) [14, 67].

Як тут не згадати вислів Людвіг Ван Бетховена: «3 сяяння ентузіазму я дозволяю вирватися мелодії. Я переслідую її. Задихаючись, я ії̈ наздоганяю. Вона знов летить і зникає, кидаючись в хаос можливих почуттів. Я знов ловлю іï, хапаю її і з насолодою обнімаю. Я помножую ії модуляціями і, нарешті, перемагаю в першій темі. Ось і вся симфонія» $[13,63]$.

В чому ж полягає суть колізії авторсько-виконавського побутування музичного твору?. Pефрлексуючи, автор найчастіше на рівні підсвідомого переживання вважає, що гра свого опусу на музичному інструменті адекватно ідеальному уявленню (перша іпостась музичного твору) і нотному запису (друга іпостась) є достатньою.

Як зауважує В. Медушевський, «в свідомості композитора, виконавця та слухача музична мова в цілому і конкретні музичні твори представлені по-різному» (курсив мій. - І. Є.) $[8,19]$.

В живому музичному дискурсі царицею $€$ інтерпретація, яка виникає в процесі гриінтонування виконавця (в тому числі, - голосом).

Оскільки авторська музична мова, яка є виразом певного авторського (композиторського) музичного стилю, завжди передує мовленню - виконавській творчості та слухацькому сприйняттю, доречно згадати визначення інтерпретації П. Рікером: «інтерпретація, скажімо ми, це робота мислення, яка полягає в розшифровці смислу, що скривається за основним смислом <...> [12, 51].

Тобто авторсько-виконавська творчо-діалектична колізія полягає ще й в постійному інтерпретуванні (переосмисленні) власних явних і скритих («зашифрованих» в зафріксованому одного разу тексті) смислів засобами мовлення кожний раз по-новому (по-іншому в синхронії з часопростором) в процесі ігрового дискурсу.

У виконавця-автора має виникати власна артистична концепція своєї ж ідеї (власного музичного твору) на переході від музичної мови нотного тексту до живого висловлювання. Виникає рівень нової художньої цілісності - «нового цілісного значення» (В. Медушевський), яка змінює смисли певних мовних одиниць.

Стає зрозумілим, що на межі (terminus) переходу знакової (композиторської) музичної мови у виконавське мовлення в досліджуваній авторсько-виконавській творчій колізії актуалізується питання риторики, спрямованої на глядача-слухача, яка є мистецтвом «захоплюючого мовлення» [15, 86-87].

Зазначу, що самому автору не завжди вдається (а часто він і не прагне до цього) під час гри свого твору точно відтворити свій же текст, який він може гнучко змінювати, демонструючи так звану «розімкнуту» (У. Еко) якість живого тексту.

Кожний раз нові «умови музикування», «форми музикування» впливають на «структуру твору» $[8,123]$ в тому числі і у випадку, коли виконавець грає свій авторський твір ${ }^{4}$, призводять до нової редакції певного опусу.

До речі, аналогічна проблемна ситуація існує і в мистецтві поезії: коли поет - читець намагається вийти на рівень художнього прочитання свого ж поетичного твору. «Вирішальна відмінність між поетом і оратором <..> в тому, що поет немає іншої мети, ніж психологічна правда в мистецтві представлення, тоді як оратор - в доповнення до всього цього - має головну ціль - перенести все в сам процес піднесення» (підкреслено мною. - І. Є.) [7, 251].

Почасти суть даної творчої колізії у конкретній жанрово-стильовій ситуації концертного виконання полягає і у послабленні уваги у зв'язку із «слабкою диференціацією ролей» $[8,122]$ - різних творчих активностей однієї особи митця-універсала: авторської і виконавської.

Висновки. Колізія авторсько-артистичної творчості існує на межі музичної мови автора і музичного мовлення виконавця (автора), композиторського музичного твору (форми) - «принципу» і виконавського музичного твору - «даності» [1].

Успішність авторсько-концертної діяльності митця знаходиться в прямій залежності від розуміння важливості акцентуації на авторсько-артистичному висловлюванні як під час прем'єри, так і в подальших презентаціях своєї музики.

Для практичного вирішення досліджуваної проблеми найважливим $є$ усвідомлення автором кінцевої точки (terminus ad quem) свого творчого продукту, до якої йому треба дійти як артисту - духовне сприйняття, естетичне враження глядача-слухача від довершеної змістовної форми авторськовиконавського музичного твору в артистичній версії.

\section{Примітки}

\footnotetext{
${ }_{1}^{1}$ Автор статті виконував усні тексти власних композицій: «Сповідь», «Балканське коло», ін., і тільки згодом їх записував.

${ }^{2}$ Це підтверджує опитування авторів-виконавців: О. Безбородька, Ю. Запорожець, К. Майденберг, А. Томльонової, б. ін.

${ }^{3}$ Термін К. Єргієвої.
} 
${ }^{4}$ Автор статті неодноразово виконував по-новому, в т. ч. за рахунок імпровізаційності, допускаючи теситурні, фрактурні, гармонічні, ін. зміни під час концертного виступу («Променад по Парижу», «Frivolite», «Одеські замальовки», б. ін.).

\section{תimepamypa}

1. Бобровский В. П. О переменности функций музыкальной формы : Москва : Музыка, 1970. 227 с.

2. Вильсон Г. Психология артистической деятельности. Таланты и поклонники. Москва : «Когито-Центр», 2001. 384 c.

3. Герасимова-Персидская Н. А. Музыка. Время. Пространство. Киев : Дух и літера, 2012. 407 с.

4. Денисов Э. В. Современная музыка и проблемы эволюции композиторской техники. Москва : Советский композитор, 1986. 207 с.

5. Єргієв І. Д. Артистичний універсум музиканта-інструменталіста кінця XX - початку XXI століття : дис. ... докт. мистецтвознав. : [спец.] 17.00.03 «Музичне мистецтво». Одеська нац. муз. акад. ім. А. В. Нежданової. Одеca, 2016. 453 c.

6. Єргієва К. І. Фортепіанна гра як жанрово-комунікативний та інтерпретативно-стильовий феномен : дис. ... канд. мистецтвознав. : 17.00 .03 «Музичне мистецтво». Одеська нац. муз. акад. ім. А. В. Нежданової. Одеса, 2019. 245 c.

7. Кьеркегор С. Заключительное ненаучное послесловие к «Философским крохам»; пер. с дат. Н. Исаевой, С. Исаева. Москва : Академический Проект, 2012. 607 с.

8. Медушевский В. В. О закономерностях и средствах художественного воздействия музыки. Москва: Музыка, 1976. 254 с.

9. Москаленко В. Г. Творческий аспект музыкальной интерпретации (к проблеме анализа). Киев : Гос. консерватория им. П. И. Чайковского, 1994. 157 с.

10. Потебня О. Із записок з теорії словесності // Збірник Пер. з рос. / Упоряд., вступ, ст., приміт. І. В. Іваньо, А. І. Колодної. - Київ : Мистецтво, 1985. 302 с.

11. Психологічний словник / під ред. В. І. Войтко. Київ : Вища школа, 1982. 215 с.

12. П. Рикер. Конфликт интерпретаций. Очерки о герменевтике. [Пер. с фрр., вступ. ст. и коммент. И. С. Вдовиной]. Москва : Академический Проект (Философские технологии), 2008. 695 с.

13. Темптон Дж. Всемирные законы жизни: Роман; Пер. с англ. Т. Л. Черезовой. - Москва : ООО «Издательство АСТ», 2003. - 610, [14], 14 с.

14. Холопов Ю. Н. Принцип классификации музыкальных фрорм. Теоретические проблемы музыкальных форм и жанров. М. : Музыка, 1971. 65-94.

15. Цицерон М. Т. Три трактата об ораторском искусстве. М. : Наука, 1972. 472 с.

16. Эко У. Сотвори себе врага. И другие тексты по случаю / пер. с ит. Я. Арьковой, М. Визеля, Е. Степанцовой. Москва: ART CORPUS, 2014. 352 с.

17. Эстетика: Словарь / под общ. ред. А. А. Беляева и др. Москва : Политиздат, 1989. 447 с.

\section{References}

1. Bobrovskiy, V. (1970). On the variability of the functions of the musical form. Moscow: Muzyka [in Russian].

2. Vilson, G. (2001). Psychology of artistic activity: Talents and fans. (A. Blase, Trans). Moscow: CogitoCentre [in Russian].

3. Gerasimova-Persidskaya, N. (2012). Music Time Space. Kyiv: Duh I litera [in Russian].

4. Denisov, E. (1986). Modern music and the problems of the evolution of composer's technique. Moscow: Sovetskyi kompozitor [in Russian].

5. lergiiev, I. D. (2016). Artistic universe of a musician-instrumentalist. Doctor's thesis. Kyiv: NMAU imeni P. I. Chaikovskoho [in Ukrainian].

6. Yerhiieva, K. I. (2019). Piano playing as a genre communicative and interpretive stylistic phenomenon. Candidate's thesis. Odessa: ONMA imeni A. V. Nezhdanovoi [in Ukrainian].

7. Kierkegaard, S. (2012). Concluding unscientific postscript to Philosophical fragments. (N. Isaieva, S. Isaiev, Trans). Moscow: Akademicheskiy Proekt [in Russian].

9. Moskalenko, V. (1994). The creative aspect of musical interpretation (to the problem of analysis). Kyiv: Gos. konservatoriya imeni P. I. Chaykovskoho [in Russian].

10. Potebnya O. (1985). From notes on the theory of literature. Compilation. (I. Ivanio, A. Kolodna, Trans). Kyiv: Mysteztvo. [in Ukrainian].

11. Psychological dictionary. (1982). V. Voitko. Kyiv: Vishcha shkola [in Ukrainian].

12. Ricoeur, P. (2008). The conflict of interpretations. Essays in Hermeneutics. (I. S. Vdovina, Trans). Moscow: Akademicheskiy Proekt [in Russian].

[in Russian].

13. Tempton, J. (2003). Worldwide laws of life: A novel. (T. Cherezova, Trans). Moscow: OOO Izdatelstvo AST.

14. Kholopov, Y. (1971). The principle of classification of musical forms. Theoretical problems of musical forms and genres. P. 65-94. Moscow: Muzyka [in Russian].

15. Cicero, M. (1972). Three treatises on public speaking. Moscow: Nauka [in Russian]. [in Russian].

16. Eco, U. (2014). Inventing the Enemy. (J. Arkova, M. Vizel, E. Stepanova, Trans). Moscow: ART CORPUS

17. Aesthetics: Dictionary. (1989). A. Belyaev. Moscow: Politizdat [in Russian]. 